\title{
Protein synthesis by hepatic mitochondria isolated from carbon tetrachloride-exposed rats *
}

\author{
Robert H. De Wit ${ }^{* *}$ and Michael J. Brabec ${ }^{* * *}$ \\ The Toxicology Program, Department of Environmental and Industrial Health, School of Public Health. The University of \\ Michigan, Ann Arbor, MI 48109 (U.S.A.)
}

(Received December 21st, 1984)

Key words: Protein synthesis; $\mathrm{CCl}_{4}$ toxicity; (Rat liver mitochondria)

Hepatic mitochondria isolated from rats $40 \mathrm{~h}$ after dosage with $1.1 \mathrm{ml} / \mathrm{kg} \mathrm{CCl}_{4}$ are uncoupled and display structural damage. Mitochondrial function returns during hepatic recovery. Because the products of mitochondrial protein synthesis are essential to mitochondrial structure and function, the effects of $\mathrm{CCl}_{4}$ on the rate of mitochondrial protein synthesis, and on the products, was studied using mitochondria from $\mathrm{CCl}_{4}$-exposed rats during the early, maximum development and resolution stages of $\mathrm{CCl}_{4}$-induced mitochondrial damage. Rates of mitochondrial protein synthesis (incorporation of $1^{35} \mathbf{S} \mid$ methionine) were elevated $300 \%$ over that of mitochondria from non-exposed rats $17 \mathrm{~h}$ after exposure; depressed by $50 \%$ at 40 $h$ and above control at $113 \mathrm{~h}$. When the radiolabeled products of incorporation were separated and examined by autoradiography, a novel, low-molecular-weight band, of approx. 9700 , was apparent $40 \mathrm{~h}$ after $\mathrm{CCl}_{4}$ exposure. $A$ band of similar molecular weight appeared when control mitochondria were incubated without an exogenous supply of ATP. Mitochondria from exposed rats which displayed rates of protein synthesis greater than control consistently had a relative increase in a band that corresponded in size to that of cytochrome oxidase subunit $\mathrm{I}$. It was concluded that the loss of mitochondrial function induced by $\mathrm{CCl}_{4}$ could not be attributed to inhibition of mitochondrial protein synthesis, and that the mitochondria may not always synthesize protein in constant proportions.

\section{Introduction}

The products of mitochondrial protein synthesis are essential tot he structure and function of the mitochondria. Three subunits of cytochrome $c$ oxidase [1-4], apocytochrome $b[5,6]$, and at least two of the ATPase subunits [7-10] have been identified as products of mitochondrial protein

* This work was done as partial fulfillment of the requirements for the Doctor of Philosophy Degree, The University of Michigan (De Wit).

** Current address: Department of Pathology and Experimental Toxicology, Warner-Lambert/Parke-Davis Pharmaceutical Research Division, Ann Arbor, MI 48105, U.S.A.

*** To whom correspondence should be addressed. synthesis. Anderson et al. [11] have identified the genes for these proteins on the human mitochondrial genome. Interruption of protein synthesis in yeast [12] and mammalian mitochondria [13] results in a depression of oxidative phosphorylation, swelling and a disappearance of cristae. These changes are similar to those produced in some cases of chemical intoxication. For example, acute $\mathrm{CCl}_{4}$ intoxication in rats results in an inhibition of oxidative phosphorylation of hepatic mitochondria $[14,15]$, accompanied by swelling, loss of cristae [16] and an increase in mitochondrial membrane permeability [17]. The disruption of mitochondrial structure and function commences 15-20 h after administration of 1.2 $\mathrm{ml} / \mathrm{kg} \mathrm{CCl}{ }_{4}$ intraperitoneally and advances for 
the next $20 \mathrm{~h}$, after which recovery of function begins $[15,17]$. We examined the effects of $\mathrm{CCl}_{4}$ on mitochondrial protein synthesis and attempted to correlate changes in protein synthesis with the development and resolution of the mitochondrial disturbances which accompany $\mathrm{CCl}_{4}$ exposure. Protein synthesis was studied in isolated mitochondria. Labeling of the protein products with $\left[{ }^{35} \mathrm{~S}\right]$ methionine allowed comparison by SDS-gel electrophoresis. It appears from this work that the uncoupling of oxidative phosphorylation and electron transport after $\mathrm{CCl}_{4}$ is not caused by an inhibition of mitochondrial protein synthesis. However, $\mathrm{CCl}_{4}$ exposure does alter both the pattern and rate of mitochondrial protein synthesis.

Portions of this work were presented at the 1983 Society of Toxicology Annual Meeting, Las Vegas, NV, U.S.A.

\section{Material and Methods}

Male Sprague-Dawley rats (Charles River Breeding Laboratories, Portage, MI), age 54-57 days, were acclimated for 10 days in a room of constant temperature and a $12 \mathrm{~h}$ light-dark cycle. A single dose of carbon tetrachloride $(1.1 \mathrm{ml} / \mathrm{kg}$ reagent grade) was injected intraperitoneally at 17 , $41,65,89$ or $113 \mathrm{~h}$ before killing. Dosing and killing occurred at 3:30 p.m. and 7:30 a.m., respectively. Livers were removed using aseptic technique, and mitochondria were isolated using sterilized equipment and solutions. The mitochondria were isolated at $0-4^{\circ} \mathrm{C}$ as described by Brabec et al. [15]. The protein concentration of the final mitochondrial suspension was determined by the Biuret method, and respiratory control ratios were determined in a biological oxygen monitor using succinate as a substrate as previously described [15]. In vitro mitochondrial protein synthesis was measured by the incorporation of $\left[{ }^{35} S\right]$ methionine into acid-precipitable material essentially as described by Beattie [18], with $\mathrm{KCl}$ increased to 140 $\mathrm{mM}$ and the addition of hydroxyproline to the amino acid mixture. Cycloheximide $(100 \mu \mathrm{g} / \mathrm{ml})$ was routinely added to inhibit cytoplasmic protein synthesis [18]. $\quad 70-100 \mu \mathrm{Ci} \quad\left[{ }^{35} \mathrm{~S}\right]$ methionine (Amersham, $>1000 \mathrm{Ci} / \mathrm{mmol}$ ) were added per reaction flask. Duplicate incubations (2 flasks/animal) were initiated by the addition of
$3.0 \mathrm{mg}$ mitochondrial protein to a total of $1.0 \mathrm{ml}$ incubation solution equilibrated at $30^{\circ} \mathrm{C}$ in a shaking water bath. Two $20 \mu \mathrm{l}$ samples (approx. $60 \mu \mathrm{g}$ protein) from each reaction flask were removed at $0,15,30$ and $45 \mathrm{~min}$ and streaked onto filter papers. The strips were immediately drained and placed into $10 \%$ ice-cold trichloroacetic acid. After $30 \mathrm{~min}$ the strips were processed through three $5 \%$ acid washes, one $95 \%$ ethanol wash, an ethanol/diethyl ether $(1: 1)$, and one $100 \%$ diethyl ether wash. The strips were placed in scintillation cocktail, and radioactivity was determined with a Packard Tri-Carb scintillation counter. The activity was normalized as $\mathrm{cpm} / \mathrm{mg}$ protein. The efficiency of counting was the same in all experiments. $20 \mu \mathrm{l}$ of the incubate was streaked onto nutrient agar and examined after $24 \mathrm{~h}$ at $37^{\circ} \mathrm{C}$ to determine bacterial contamination. The remaining incubation mixture was diluted with $3.0 \mathrm{ml} 0.25 \mathrm{M}$ sucrose and $5 \mathrm{mM}$ cold methionine. Mitochondria were pelleted at $7000 \times \mathrm{g}$ and washed twice in the sucrose/methionine solution. The final pellet was dissolved in $0.25 \mathrm{ml}$ of $10 \%$ SDS with heating and $15 \mu \mathrm{l}$ (74 $\mu \mathrm{g}$ of protein) subjected to vertical slab SDS-polyacrylamide electrophoresis, as adapted by the Canalco Company from the system of Laemmli [19]. The gel was fixed, embedded with Enhance $^{\mathbb{B}}$, and dried onto filter paper. Fluorography was performed by placing the dried gel in intimate contact with Kodak XR-Omat film at $-76^{\circ} \mathrm{C}$ for 3-4 days. The fluorographs were scanned with an Ortec Model 3410 densitometer with an integrator function.

\section{Results}

Because the rates of incorporation of $\left[{ }^{35}\right.$ S $]$ methionine by the control mitochondria varied $10 \%$ between experiments, treated and control mitochondria were always compared within the same experiment. This variation was analyzed by linear regression and was shown to be independent of any of the following: specific activity of the isotope, amount of isotope, respiratory control ratios and total amount of methionine. Fig. 1 compares the effects of using an exogenous or an endogenous energy source. The incorporation of $\left[{ }^{35} \mathrm{~S}\right]$ methionine into acid-precipitable material after $\mathbf{4 5} \mathrm{min}$ in the presence of ADP and succinate 


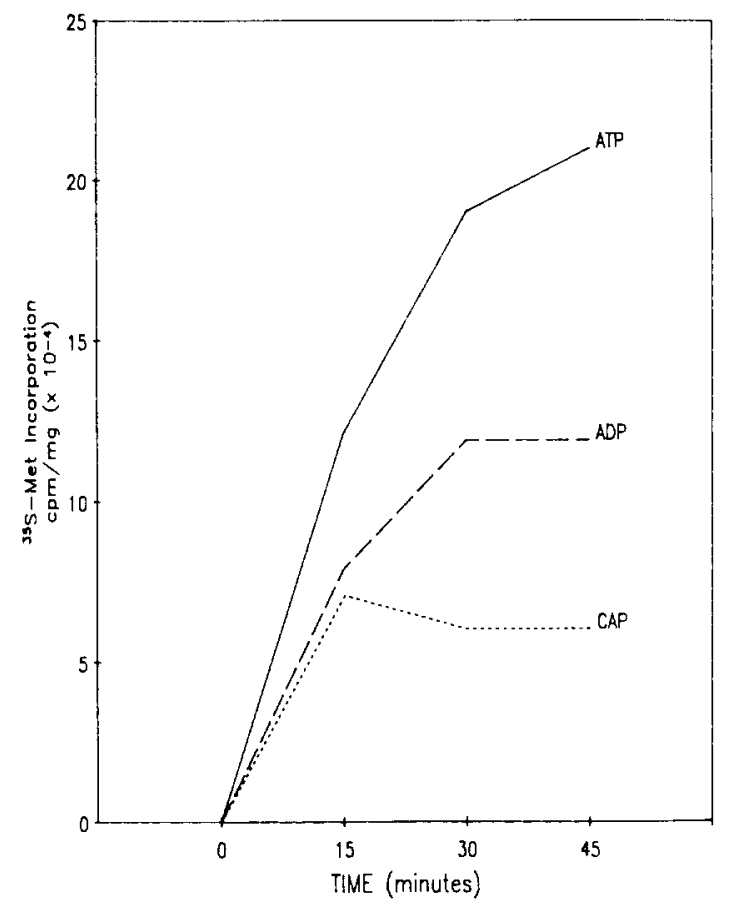

Fig. 1. Incorporation of $\left[{ }^{35} \mathrm{~S}\right]$ methionine into protein by rat hepatic mitochondria. Samples were incubated in duplicate reaction flasks as described in Methods. ATP: Mitochondria incubated in the presence of $2 \mathrm{~mm} \mathrm{ATP}, 5 \mathrm{mM}$ phosphoenolpyruvate and $33 \mu \mathrm{g} / \mathrm{ml}$ pyruvate kinase. ADP: mitochondria incubated in the presence of $2 \mathrm{mM} A D P$ and $10 \mathrm{mM}$ succinate. CAP: incubations contained chloramphenicol $(120 \mu \mathrm{g} / \mathrm{ml})$ and the ATP/phosphoenolpyruvate/pyruvate kinase energy system. Other conditions described in Methods.

(endogenous ATP supply) was $57 \%$ of that in the presence of ATP, phosphoenolpyruvate and pyruvate kinase (exogenous ATP supply). The addition of $120 \mu \mathrm{g} / \mathrm{ml}$ chloramphenicol typically reduced $\left[{ }^{35} \mathrm{~S}\right]$ methionine incorporation by $70 \%$. Table I shows the in vitro incorporation of $\left[{ }^{35}\right.$ S]methionine by hepatic mitochondria isolated after a single intraperitoneal injection of $\mathrm{CCl}_{4}$. Mitochondria isolated from rats $17 \mathrm{~h}$ after $\mathrm{CCl}_{4}$ displayed rates of $\left[{ }^{35} \mathrm{~S}\right]$ methionine incorporation $175-430 \%$ greater than those of control. Thus, protein synthesis is stimulated at $17 \mathrm{~h}$ post- $\mathrm{CCl}_{4}$, when the depression of the respiratory control ratios begins. The incorporation of $\left[{ }^{35} \mathrm{~S}\right]$ methionine at $41 \mathrm{~h}$ was approx. $50 \%$ of control values. Mitochondria at this time display maximum uncoupling [15]. The incorporation of $\left[{ }^{35} \mathrm{~S}\right]$ methionine was the same as control at $65 \mathrm{~h}$ and at $89 \mathrm{~h}$ after
TABLE I

$\left[{ }^{35}\right.$ S]METHIONINE INCORPORATION BY HEPATIC MITOCHONDRIA

Incorporation of $\left[{ }^{35} \mathrm{~S}\right]$ methionine by hepatic mitochondria isolated from rats after $1.1 \mathrm{ml} \mathrm{CCl}_{4} / \mathrm{kg}$. Mitochondria were isolated aseptically and incubated with $\left[{ }^{35} \mathrm{~S}\right]$ methionine as described in Methods. Total acid-precipitable radioactivity was determined after $45 \mathrm{~min}$ of incubation.

\begin{tabular}{ll}
\hline $\begin{array}{l}\text { Hours post- } \\
\text { CC14 }\end{array}$ & $\begin{array}{l}\text { \% of control }\left[{ }^{35} \text { S }\right] \text { methionine } \\
\text { incorporation }\end{array}$ \\
\hline 17 & 176 \\
17 & 433 \\
41 & 49 \\
41 & 47 \\
65 & 103 \\
89 & 113 \\
113 & 160 \\
\hline
\end{tabular}

control, but was elevated (160\%) at the $113 \mathrm{~h}$ time point. The respiratory control ratio values of mitochondria isolated $65-113 \mathrm{~h}$ after $\mathrm{CCl}_{4}$ progressively improved to normal values. Fig. 2 shows composite fluorographs of SDS gels of labeled mitochondrial proteins. For each experiment, a representative sample lane of the treated and control patterns are shown. The other lanes were of identical pattern and intensity, except where noted. Similarity in the pattern of proteins synthesized is apparent, although a marked contrast in intensity exists between some treated and control samples. Since approximately equal amounts of protein were added to each lane, the variation in intensity is a representation of the differences in $\left[{ }^{35} \mathrm{~S}\right]$ methionine incorporation. In Fig. 2, a sample from $17 \mathrm{~h}$ mitochondria (lane 2) shows an increase in intensity as compared to its control (lane 4), as would be predicted from the incorporation data. Chloramphenicol effectively inhibited the synthesis of mitochondrial protein (lane 3). A sample from 41 h mitochondria (Fig. 2, lane 5) shows the expected decrease in the intensity of the bands. A novel low-molecular-weight band (about 9700) appears in the $41 \mathrm{~h}$ sample (lowest arrow). Control and treated mitochondria incubated in ADP also show this novel low-molecular-weight band (data not shown). The intensity of the $65 \mathrm{~h}$ mitochondrial sample in Fig. 2 (lane 7) is similar to its control (lane 8). Eliminating cycloheximide had no effect 


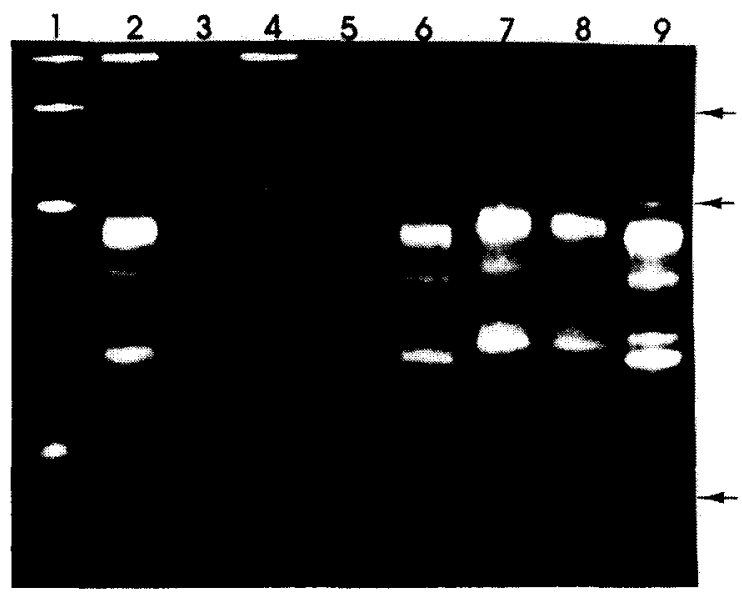

Fig. 2. Composite fluorograph of SDS-polyacrylamide gel patterns from control rats and rats post-exposure to $\mathrm{CCl}_{4}$. Mitochondrial proteins were solubilized as described in Methods following $45 \mathrm{~min}$ incubation with $\left[{ }^{35}\right.$ S] methionine. $75 \mu \mathrm{g}$ protein was applied per gel lane. Lane $1,{ }^{14} \mathrm{C}$-labeled standards $\left(M_{\mathrm{r}} 92500,46000,30000,12300\right)$; lane 2, proteins from $\mathrm{CCl}_{4}$ mitochondria $(17 \mathrm{~h})$; lane 3 , control mitochondria plus chloramphenicol $(120 \mu \mathrm{g} / \mathrm{ml})$; lane 4 , proteins from control mitochondria in $17 \mathrm{~h}$ experiment; lane 5, proteins from $\mathrm{CCl}_{4}$ mitochondria $(41 \mathrm{~h})$; lane 6 , proteins from control mitochondria in $41 \mathrm{~h}$ experiment; lane 7 , proteins from $\mathrm{CCl}_{4}$ mitochondria $(65 \mathrm{~h})$; lane 8 , proteins from control mitochondria in $65 \mathrm{~h}$ experiment; lane 9, proteins from $\mathrm{CCl}_{4}$ mitochondria $(65 \mathrm{~h})$.

on the pattern of protein synthesized by the mitochondria (data not shown), which confirms that the mitochondrial isolation was without any effective cytoplasmic ribosomal contamination. The $65 \mathrm{~h}$ sample in lane 9 shows three unusual

\section{TABLE II}

INCREASE IN THE AREA ASSOCIATED WITH THE 42000 BAND

\begin{tabular}{lcl}
\hline Treatment & $\begin{array}{l}\text { Hourst post- } \\
\mathrm{CCl}_{4}\end{array}$ & \% total area ${ }^{\text {a }}$ \\
\hline Control & Expt. 1 & $38.0 \pm 3.4$ \\
$\mathrm{CCl}_{4}$ & 17 & $54.1 \pm 1.3^{\mathrm{b}}$ \\
$\mathrm{Control}$ & Expt. 2 & $33.6 \pm 0.2$ \\
$\mathrm{CCl}_{4}$ & 17 & $43.0 \pm 4.9$ \\
$\mathrm{Control}$ & - & $42.5 \pm 0.5$ \\
$\mathrm{CCl}_{4}$ & 89 & $50.3 \pm 1.3^{\mathrm{b}}$ \\
$\mathrm{Control}$ & - & $46.2 \pm 0.5$ \\
$\mathrm{CCl}_{4}$ & 113 & $56.1 \pm 1.0^{\mathrm{b}}$ \\
\hline
\end{tabular}

a Mean of integrator values for percentage of total area \pm S.D.

${ }^{b} P<0.01$. high-molecular-weight bands (the upper arrow marks the 88500 and 80800 bands; the middle arrow marks the 51800 band). The bands were equally evident when the electrophoresis of the sample was repeated on another gel (data not shown). These bands appeared only in this sample. A scanning densitometer verified the three novel bands in the one $65 \mathrm{~h}$ sample and the low-molecular-weight bands in the $41 \mathrm{~h}$ and ADP samples. Integration of the area under the peaks indicated an increase of the band of 42000 estimated molecular weight in all samples in which there was an increase in total $\left[{ }^{35} \mathrm{~S}\right] \mathrm{methionine} \mathrm{incorporation}(17$, 89 and $113 \mathrm{~h}$ samples, Table il). The increase of the 42000 band was independently confirmed with a planimeter. The location of this band corresponds with that associated with cytochrome $c$ oxidase subunit $I[3,11]$.

\section{Discussion}

This work has shown that the inhibition of oxidative phosphorylation after an acute dose of $\mathrm{CCl}_{4}$ is not due to an inhibition of mitochondrial protein synthesis. The increase in protein synthesis $17 \mathrm{~h}$ post- $\mathrm{CCl}_{4}$ coincides roughly with the initial inhibition of mitochondrial respiration and oxidative phosphorylation. Despite the increased synthesis of mitochondrial protein, mitochondrial function degrades to a nadir at $40 \mathrm{~h}$. Two explanations for the increased synthesis at $17 \mathrm{~h}$ may be considered. It has been proposed that in yeast systems the availability of cytoplasmic protein products influences mitochondrial protein synthesis $[20,21]$. Pavittranon et al. [22] and Brabec et al. [15] have shown an increase in rat hepatic cytoplasmic protein synthesis at $20 \mathrm{~h}$ post- $\mathrm{CCl}_{4}$. The increase in mitochondrial protein synthesis reported here could represent a response to the increase in synthesis of protein in the cytoplasm. A second explanation would be simply that the intramitochondrial pool of $\left[{ }^{35}\right.$ S]methionine was greater, perhaps because changes in the lipid content might alter permeability of the mitochondrial membranes at $17 \mathrm{~h}$ post- $\mathrm{CCl}_{4}$ [17]. However, this is not likely because (1) the mitochondria are structurally intact, since respiratory control ratio values were similar to control values, and (2) a selective increase in the radioactivity associated 
with the band of 42000 occurred. This band corresponds to the cytochrome $c$ oxidase subunit $I[2,3]$. This specific increase would not be observed if the increase in total protein synthesis was simply a greater availability of $\left[{ }^{35}\right.$ S]methionine. Burke and Rubin [23] reported a decrease in total mitochondrial protein synthesis after ethanol exposure with a selective decrease of proteins in the same molecular weight region. Therefore, it would appear that the increase at $17 \mathrm{~h}$ is not due to permeability changes and that the synthesis of cytochrome $c$ oxidase subunit I is sensitive to relative increases or decreases of mitochondrial protein synthesis. It was considered that the reduced incorporation of $\left[{ }^{35} \mathrm{~S}\right]$ methionine at $41 \mathrm{~h}$ could be due to the fasting exhibited by the intoxicated animals. However, an experiment with mitochondria isolated from a control animal fasted for $40 \mathrm{~h}$ incorporated $\left[{ }^{35} \mathrm{~S}\right]$ methionine at the same rate as controls (results not shown).

The importance of ATP to mitochondrial protein synthesis is well-known [31,32], and is illustrated by the results in Fig. 1. The decrease in protein synthesis at $41 \mathrm{~h}$ therefore could be due to a decrease in intramitochondrial ATP concentrations. Mitochondria are uncoupled at $41 \mathrm{~h}$ after $\mathrm{CCl}_{4}[14,15,17]$ and ATP concentrations are depressed [24]. Also, mitochondria accumulate 15times the normal amount of $\mathrm{Ca}^{2+}$ after $\mathrm{CCl}_{4}$ exposure [14], which occurs at the expense of ATP production [25]. The mitochondrial membrane carrier for external ATP requires a transmembrane potential gradient [26] which would be abolished by the huge increase in intramitochondrial $\mathrm{Ca}^{2+}$. Therefore, sufficient ATP may not be available to drive mitochondrial protein synthesis. Protein synthesis may be further inhibited in uncoupled mitochondria because of a failure to import proteins. Since the processing of some cytoplasmically synthesized proteins depends on a transmembrane potential, uncoupling would prevent processing [27]. The lack of cytoplasmic products could depress mitochondrial translation rates.

The reduction in mitochondrial protein synthesis at $41 \mathrm{~h}$ post- $\mathrm{CCl}_{4}$ is apparently insufficient to slow liver regeneration. Van den Bogert et al. [28] have shown that a reduction of $86 \%$ of mitochondrial protein synthesis is necessary to slow hepatic regeneration after partial hepatec- tomy. The novel 9700 band in $41 \mathrm{~h}$ mitochondrial samples also appears in mitochondria incubated without external ATP. There is no apparent reason other than a decrease in ATP, why this band should be common to these two situations.

The appearance of three novel high-molecularweight bands in the one sample is interesting (Fig. 2 ). While it is possible that this alteration is due to $\mathrm{CCl}_{4}$ exposure, this could also be a random event. Hauswirth and Laipis [29] have shown that mitochondrial genetic changes may be very common. Bhat et al. [30] found four new protein bands when protein products of hepatic mitochondria were examined after acute exposure of rats to aflatoxin $B_{1}$. The three bands in Fig. 2 also suggest that the proteins synthesized by rat hepatic mitochondria are not invariant. In conclusion, it has been shown that acute $\mathrm{CCl}_{4}$ intoxication has obvious effects on mitochondrial protein synthesis. However, it is unlikely that an inhibition of mitochondrial protein synthesis during the early phase of $\mathrm{CCl}_{4}$ intoxication is responsible for the initial degradation of mitochondrial structure and function. The stimulation of synthesis may reflect the changes in liver attempting to recover after acute, chemically induced damage.

\section{Acknowledgement}

This work was supported in part by NIEHS T32ES07062 and ES01919.

\section{References}

1 Schatz, G. and Mason, T.L. (1974) Annu. Rev. Biochem. 43, $51-87$

2 Rascatti, R.J. and Parsons, P. (1979) J. Biol. Chem. 254, 1594-1599

3 Wilson, G., Hodges, R. and Hare, J.F. (1981) J. Biol. Chem. 256, 5197-5203

4 Kolarov, J., Kuzela, S., Wielburski, A. and Nelson, B.D. (1981) FEBS Lett. 126, 61-65

5 Krieke, J., Bechmann, H., Van Henert, F.J., Schweyen, R.S., Boer, P.H., Kandewitz, F. and Groot, G.S. (1979) Eur. J. Biochem. 101, 607-617

6 Gellerfors, P. and Nelson, B.D. (1981) Biochem. Biophys. Res. Commun, 99, 170-175

7 Tzagoloff, A. (1971) J. Biol. Chem. 246, 3050-3056

8 Orian, J.M., Murphy, M. and Marzuki, S. (1981) Biochim. Biophys. Acta. 652, 234-239

9 Kuzela, S., Luciakova, K. and Lakota, J. (1980) FEBS Lett. $114,197-201$ 
10 De Jong, L., Holtrop, M. and Kroon, A.M. (1980) Biochim. Biophys. Acta. 608, 32-38

11 Anderson, S., Bankier, A.T., Barrell, B.G., De Bruijn, M.H.L., Coulson, A.R., Drouin, J., Eperon, I.C., Nierlich, D.P., Roe, B.A., Sanger, F., Schreier, P.H., Smith, A.J.H., Staden, R. and Young, I.G. (1981) Nature 290, 457-465

12 Clark-Walker, G.D. and Linnane, A.W. (1967) J. Cell Biol. $34,1-14$

13 King, M.E., Godman, G.C. and King, D.W. (1972) J. Cell Biol. 53, 127-142

14 Theirs, R.E., Reynolds, E.S. and Vallee, B.L. (1960) J. Biol. Chem. 235, 2130-2133

15 Brabec, M.J., Gray, R.H. and Bernstein, I.A. (1974) Biochem. Pharm. 23, 3227-3238

16 Bassi, M. (1960) Exp. Cell. Res. 20, 313-323

17 Brabec, M.J., Dolci, E.D. and Bernstein, I.A. (1980) in Molecular Basis of Environmental Toxicology (Bhatnajar, N.J., ed.), pp. 135-149, Ann Arbor Science Publishers, Ann Arbor

18 Beattie, D.S. (1979) Methods Enzymol. 56, 17-29

19 Laemmli, U.K. (1970) Nature 227, 680-685

20 Tzagoloff, A. (1982) Mitochondria, Plenum Press, New York
21 Poyton, R.O. and Kavanagh, J. (1976) Proc. Natl. Acad. Sci. USA 73, 3947-3951

22 Pavittranon, S., Nelson, J. and Brabec, M.J. (1983) The Toxicologist. 3, 97

23 Burke, J.P. and Rubin, E. (1979) Lab Invest. 41, 393-400

24 Dianzani, M.U. (1957) Biochem. J. 65, 116-124

25 Lehninger, A.L., Carafoli, E. and Rossi, C.S. (1967) Adv. Enzym. 29, 259-320

26 Klingenberg, M. (1970) Essays Biochem. 6, 119-159

27 Schatz, G. and Butow, R.A. (1983) Cell. 32, 316-318

28 Van den Bogert, C., Lont, M., Mojet, M. and Kroon, A.M. (1983) Biochim. Biophys. Acta 722, 393-400

29 Hauswirth, W.W. and Laipis, P.J. (1982) Proc. Natl. Acad. Sci USA 79, 4686-4690

30 Bhat, N.K., Emeh, J.K., Niranjan, B.G. and Avadhani, N.G. (1982) Can. Res. 42, 1876-1880

31 Wheeldon, L.W. and Lehninger, A.L. (1966) Biochemistry $5,3533-3545$

32 Lamb, A.J., Clark-Walker, G.D. and Linnane, A.W. (1968) Biochim. Biophys. Acta 161, 415-427 